\title{
Formulation optimization and antioxidant test for Self-nano emulsifying drug delivery system of soursop leaves (Annona muricata $L$.) chloroform extract using candlenut oil as oil phase
}

\author{
Anif Nur Artanti ${ }^{* 1}$, Anggraini Febriyanty ${ }^{2}$, Fea Prihapsara ${ }^{2}$, Dian Eka Ermawati ${ }^{1}$ \\ ${ }^{l}$ Department of Diploma 3 Pharmacy, Sekolah Vokasi, Universitas Sebelas Maret \\ Jl. Kolonel Sutarto No150K, Jebres, Surakarta, Central Java, Indonesia \\ ${ }^{2}$ Department of Pharmacy Faculty of Mathematics and Natural Sciences, Universitas Sebelas Maret \\ Jl.Ir Sutami No 36A Kentingan, Surakarta, Central Java, Indonesia
}

Submitted: 05-09-2020

Reviewed: 18-09-2020

Accepted: 02-03-2020

\begin{abstract}
Soursop leaves (Annona muricata L.) chloroform extract has an anticancer agent that can be developed for traditional medicine preparation, even though the extract's solubility is low in the water. This study aims to generate new soursop leaves chloroform extract in the Self-Nano Emulsifying Drug Delivery System (SNEDDS). The expected result is that the solubility increases so that the drug delivery system is more effective. The extraction process of soursop leaves uses the percolation method with chloroform as a solvent. It used tween 80 and cremophore E.L. as surfactant, propylene glycol as a cosurfactant, and candlenut oil as a carrier, to make the SNEDDS formulation. Then performed a comparison between the optimal parameters for the physical properties of the SNEDDS formulation with the predictive Simplex Lattice Design (SLD) formulation with the students' t-test statistical analysis [p>0.05]. Then carried out several tests such as loading dosage extractability, accelerated stability test, particle size, and zeta potential. Furthermore, the antioxidant test was carried out using the DPPH reagent. The optimum composition of candlenut oil, propylene glycol, a mixture of tween 80, and cremophor E.L. based on SLD is 12\%: 22\%: $66 \%$, respectively. The SNEDDS optimum formulation for chloroform extract of soursop leaves produces a stable nanoemulsion, homogenous. It has a transmittance value of $90.58 \% \pm 0.151$, emulsification time of $59.44 \pm 1.763$ seconds, and a value of separation phase 1. The physical formulation test results showed no significant difference between observations with predictive design expert software. SNEDDS can produce $25.0 \mathrm{mg}$ of soursop chloroform extract with particle size $411.4 \mathrm{~nm}$, polydispersion index 0.482 , and zeta potential $34.2 \mathrm{mV}$. IC50 value in $36.28 \mathrm{ppm}$ indicated the antioxidant potential of the SNEDDS formulation for chloroform extract of soursop leaves is high.
\end{abstract}

Keywords: antioxidant, chloroform, soursop, candlenut oil, SNEDDS

\footnotetext{
*Corresponding author:

Anif Nur Artanti

Department of Diploma 3 Pharmacy, Sekolah Vokasi, Universitas Sebelas Maret, Indonesia J1. Kolonel Sutarto No150K, Jebres, Surakarta, Central Java, Indonesia Email : anif.apt@staff.uns.ac.id
} 


\section{INTRODUCTION}

Soursop leaves (Annona muricata L.) is a member of Annonaceae family. It contains acetogenin compounds, an anticancer, anticonvulsant, anti-arthritis antiparasitic, antimalarial, hepatoprotective, and antidiabetic activity (Moghadamtousi et al., 2015). Chloroform extract of soursop leaves can reduce ATP production and induce apoptosis of cancer cells as an inhibitory mechanism of the mitochondrial complex (An et al., 2016). However, soursop leaves chloroform extract solubility was low on polar media. This study aims to develop new soursop leaves chloroform extract in SNEDDS, bringing nanoparticle systems to increase drug absorption and bioavailability in the body. It is also to measure the antioxidant activity of SNEDDS preparations. The testing process uses DPPH reagent toward the optimal SNEDDS formulation for soursop leaves. This method is simple, fast, and easy to filter out radical scavenger activity (Pratiwi et al., 2014).

To reached mathematical data preparation and interpretation, the composition of SNEDDS system's formulations was optimized. The D-optimal method was used to evaluate several variables to reduce the number of trials. SNEDDS can spontaneously form nanoemulsions when they encounter the water phase through light agitation in the stomach due to its mixture of oil, surfactant, and co-surfactant (Makadia et al., 2013). Small particles of the active substance can significantly increase the surface area, which increases the level of solubility, dissolution rate, and absorption of active substances in the body (Lovelyn and Attama, 2011). Increasing the distribution of drugs to the target is done directly because the nanoemulsion can permeate between cells (Martien et al., 2012). Nanoparticles have a size of below 1 micrometer and enter cells under 1 micrometer in size (Desmiaty et al., 2015). The suitable oil for the SNEDDS formulation is an oil with a high-medium chain fatty acid content (Goyal et al., 2012). The fatty oil from candlenut seeds contains unsaturated fatty acids with oleic acid levels $10.54 \%$, linoleic acid $48.56 \%$, linolenic acid $28.5 \%$, and saturated fatty acids $12.56 \%$ (Arlene, 2013). The constituent components are mostly linoleic acid, which is a long-chain carbon bond. The fatty acids in candlenut oil are long-chain triglycerides (> 12 carbon). Oil with long-chain triglycerides has better hydrophobic drug solubilization ability (Carmona et al., 2015).

Therefore, candlenut oil is suitable for use as a carrier oil in nanoemulsion preparations. Still, the optimum composition of oil, surfactant, and cosurfactant has not existed before, so it needs to be optimized. Optimization is an experimental method or design to facilitate the mathematical arrangement and interpretation of data. The D-Optimal method is used to determine the formulation given the limitations used in each ingredient component. Many types of designs can be used, such as Simplex Lattice Design (SLD) and D-Optimal, to optimize the formulation. D-Optimal is a method to minimize the coefficient regression prediction's overall variant by maximizing the information matrix's determinant value (Zen et al., 2015). This study uses the D-Optimal mixed design method and the State Ease Dx 9 Trial Expert Design software (Maharani, 2016). This multivariate statistical method has the advantage of being able to evaluate several variables to lower the number of trials. Another benefit is that it can identify interactions statistically, such as the composition of different oils or fatty acids, to produce optimal formulations with intended characteristics (Borhan et al., 2014).

\section{MATERIALS AND METHODS \\ Materials}

This study used the 4th to 10th leaves from the tip of the twig (Tawangmangu, Karanganyar); chloroform pro analytic (Merck); TLC plate (silica gel 60 GF254 Merck), ethyl acetate, methanol, N-hexane pro analytic, candlenut oil (Cahaya Naturals), cremophor E.L. (Merck), tween 80 (Bratachem), propylene glycol (Bratachem), $\mathrm{NaCl}$ (Merck), $\mathrm{HCl}$ (Merck). The 
tools use are UV-Vis Spectrophotometer (Thermo Scientific), glassware (Pyrex), rotary evaporator (BUCHI), and digital camera (Sony).

\section{Methods \\ Preparation of chloroform extract of soursop leaves (Annona muricata $L$.)}

After being selected from the tree, fresh soursop leaves has been washed and sorted. Then, it has been mashed using a blender to obtain soursop leaf powder. The percolation method used 1 liter of chloroform solvent at room temperature to wet 100 grams of soursop leaves powder. This process takes 24 hours. Then drain the new solvent and keep it tightly closed to get the percolation results through the percolator tap. The percolated liquid extract was evaporated with a solvent to get a thick result, using a rotary evaporator and a waterbath.

\section{Preparation of self nano emulsifying drug delivery system (SNEDDS)}

The formulation was optimized using Design-Expert software and obtained 16 formulations with candlenut oil, surfactant, and cosurfactant compositions. The surfactant used was a combination of cremophor E.L. and Tween 80 (15\%: 85\%). The variable responses listed are the percent transmittance value, the emulsification time on the AGF media, and the separation phase value. Adding little by little $100 \mathrm{mg}, 50 \mathrm{mg}$, and $25 \mathrm{mg}$ soursop leaves extract to the formulation was done to get SNEDDS dosage. After that, the mixture was sonicated for 10 minutes and incubated at $45^{\circ} \mathrm{C}$ for 15 minutes. Then the homogenity of the nanoemulsion was under monitored. The formulation can liquidate all extracts entirely then be used as a loading dose (Savale, 2015).

\section{Characterization of Self Nano Emulsifying Drug Delivery System (SNEDDS) Measurement of transmittance value (\% T)}

A $1 \mathrm{~mL}$ SNEDDS was diluted in distilled water then measured by UV-Vis Spectrophotometer at wavelength of $650 \mathrm{~nm}$.

\section{Observation of Emulsification Time}

The emulsification time was done on SNEDDS soursop leaves extract in an artificial gastric fluid (AGF) medium. Each 1 Liter AGF medium contains 2 grams of $\mathrm{NaCl}$ and $7 \mathrm{~mL}$ of $37 \% \mathrm{HCl}$ with a $\mathrm{pH}$ value of $1.2 .50 \mathrm{~mL}$ of media is conditioned at $37^{\circ} \mathrm{C}$ above the magnetic stirrer at 100 rpm. SNEDDS is dripped as much as $200 \mu \mathrm{L}$ into the medium-fast. Visual monitoring was done until it becomes nanoemulsion. It is then done by looking at the media solution's transparency.

\section{Observation of thermodynamic stability (phase of separation)}

The statement of nanoemulsion thermodynamic stability is by centrifugation. A total of 1.5 $\mathrm{mL}$ of nanoemulsion was inserted into the microtube and centrifuged at $3500 \mathrm{rpm}$ for 3 times 10 minutes. After that, it calculated the SNEDDS separation phase by looking at the separating phase's height.

\section{Optimization of SNEDDS formulation of soursop leaves extract}

The best formulation results are then optimized using the D-Optimal method in the State Ease Expert 9 Trial Design application with Tween 80 (independent variable), cremophore and propylene glycol with transmittance value (dependent variable), then separation phase and emulsification time in AGF. The optimal formulation of SNEDDS chloroform extract of soursop leaves obtained from optimization using D-Optimal method was tested its physical stability, including \% transmittance response, phase separation and emulsification time in AGF. The optimum formulation prediction was then verified by performing three times SNEDDS formulations using the one sample t-test on the SPSS 22 program at a 95\% confidence level. If the verification results are not significantly different from the predicted results, it means valid, and a pvalue is found to be $<0.05$. 


\section{Identification of the compound content in the snedds of soursop leaves extract}

The next process is to evaluate the active compounds of soursop leaves in SNEDDS using Thin Layer Chromatography. The stationary phase used is silica gel 60 GF254, and the mobile step used is chloroform : ethyl acetate (7: 3).

\section{Antioxidant activity test using the DPPH reagent}

In this study, the SNEDDS antioxidant activity test of soursop leaves chloroform extract was performed using a DPPH reagent. A total of $1.0 \mathrm{~mL}$ of samples with various concentrations was added with $1.0 \mathrm{~mL}$ of DPPH solution $(0.4 \mathrm{mM})$ into a $5.0 \mathrm{~mL}$ volumetric flask, then added with methanol pro analysis until the mark, then homogenized incubated at $37 \mathrm{oC}$ during the operational time. The absorption was measured at the maximum wavelength using UV-Vis spectrophotometry. Then it was estimated and replicated the absorbance three times. It used quercetin with various concentration series to compare, which were treated the same as the sample, blank using methanol pro analysis (Desmiaty et al., 2015).

\section{Data Analysis}

The proportion of optimum composition of SNEEDS formulation was obtained by DOptimal method using Design Expert 9 Trial software. The result of observation was compared with prediction by SPSS t-test.

\section{RESULTS AND DISCUSSION}

The purpose of the extract making is to receive a soursop leaves extract used as SNEDDS active compound. The initial stage is the sampling of soursop leaves in Karanganyar area. The next step was making powder, then doing percolation with chloroform solvent. The results gained were thick viscous extract 51,23 gram and yield of 6,4\%. The moisture content of chloroform extract of soursop leaves was $1.3 \%$. The SNEDDS formulation formation was done using the D-Optimal method with the State Ease Expert 9 Trial Design software. The composition used was soursop leaves extract as the active substance, cremophore and tween 80 as surfactant, and propylene glycol as a co-surfactant. The ratio of upper and lower limits of material composition were 1: 5: 1, that was why gained the SNEDDS formulation as in Table 1. The combination of surfactants used was tween 80 and cremophores with a ratio of $85 \%: 15 \%$. The candlenut oil was used because it has long-chain triglyceride bonds. It can increase the bioavailability of highly lipophilic drugs by stimulating its lymphatic transport (Akula et al., 2014).

The percent transmittance test was used to find out the clarity of emulsion produced by SNEDDS formulation of soursop leaves chloroform extract. Emulsions are said to be nanometers if they have a transmitter value above $90 \%$ (Costa et al., 2012). Another parameter says that SNEEDS is good if it has an emulsification time under 2 minutes (Nasr et al., 2016). The separation phase is good when F approaches 1 (Cicilia, 2016). D-optimum is the method used to optimize the proportion of formulation components. The amount of candlenut oil (A), surfactant: Tween 80-Croduret (B), and co-surfactant: propylene glycol (C) were selected as independent factors. The properties of mixed profiles are determined by the basis of the Bolton equation: $Y=\alpha 1$ (A) $+\alpha 2$ (B) $+\alpha 3$ (C) $+\alpha 12$ (A) (B) $+\alpha 13$ (A) (C) + A23 (B) (C) $+\alpha 123$ (A) (B) (C). Y is the response, $\mathrm{ABC}$ is the proportion of the component, and $\alpha$ is the coefficient 
Table 1. SNEDDS formulation of chloroform extract from soursop leaves using State-Ease Design Expert 9 Trial

\begin{tabular}{cccccccc}
\hline \multirow{2}{*}{ Formula } & \multicolumn{2}{c}{$\begin{array}{c}\text { Percentage of Oil [A], Surfactant [B] and } \\
\text { CoSurfactant [C] based on D-Optimal }\end{array}$} & \multicolumn{2}{c}{$\begin{array}{c}\text { Result of SNEDDS Physical Stability } \\
\text { Parameters of Soursop Leaf } \\
\text { Chloroform Extract }\end{array}$} \\
\cline { 2 - 8 } & $\begin{array}{c}\text { Oil } \\
(\%)\end{array}$ & $\begin{array}{c}\text { Surfactant } \\
(\boldsymbol{\%})\end{array}$ & $\begin{array}{c}\text { Co- } \\
\text { Surfactant } \\
(\boldsymbol{\%})\end{array}$ & $\begin{array}{c}\text { Extract } \\
(\text { gram) }\end{array}$ & $\begin{array}{c}\text { Transmit- } \\
\text { tance } \mathbf{( \% )}\end{array}$ & $\begin{array}{c}\text { Emulsification } \\
\text { Time } \\
\text { (seconds) }\end{array}$ & $\begin{array}{c}\text { Separation } \\
\text { Phase (value } \\
\text { F=1) }\end{array}$ \\
\hline 1 & 17.33 & 65.33 & 17.33 & 0.1 & 62.33 & 97 & 0.98 \\
2 & 12.00 & 66.00 & 22.00 & 0.1 & 87.08 & 67 & 0.97 \\
3 & 22.00 & 63.00 & 15.00 & 0.1 & 57.58 & 104 & 0.98 \\
4 & 22.00 & 66.00 & 12.00 & 0.1 & 78.50 & 120 & 0.99 \\
5 & 18.00 & 70.00 & 12.00 & 0.1 & 80.40 & 113 & 0.98 \\
6 & 22.00 & 60.00 & 18.00 & 0.1 & 52.93 & 85 & 0.97 \\
7 & 12.00 & 70.00 & 18.00 & 0.1 & 91.45 & 114 & 0.98 \\
8 & 12.00 & 70.00 & 18.00 & 0.1 & 91.59 & 102 & 0.97 \\
9 & 18.00 & 60.00 & 22.00 & 0.1 & 87.15 & 114 & 0.98 \\
10 & 12.00 & 66.00 & 22.00 & 0.1 & 91.23 & 84 & 0.99 \\
11 & 19.67 & 65.67 & 14.67 & 0.1 & 79.09 & 84 & 0.98 \\
12 & 18.00 & 70.00 & 12.00 & 0.1 & 80.43 & 83 & 0.97 \\
13 & 22.00 & 60.00 & 18.00 & 0.1 & 91.24 & 83 & 0.98 \\
14 & 15.00 & 63.00 & 22.00 & 0.1 & 85.14 & 100 & 0.97 \\
15 & 18.00 & 60.00 & 22.00 & 0.1 & 82.41 & 81 & 0.98 \\
16 & 15.00 & 70.00 & 15.00 & 0.1 & 86.68 & 154 & 0.99 \\
\hline
\end{tabular}

Description: total weight of SNEDDS system 4 grams. The extract was used $100 \mathrm{mg}$

Table 2. Result of analysis Software Design Expert: physical stability parameters SNEDDS extract of soursop leaves based on mathematical model and ANOVA statistical analysis

\begin{tabular}{cccc}
\hline $\begin{array}{c}\text { SNEDDS } \\
\text { physical } \\
\text { stability } \\
\text { response }\end{array}$ & Mathematical Equations & $\begin{array}{c}\text { Mathematical } \\
\text { Model }\end{array}$ & $\begin{array}{c}\text { p-value } \\
\text { [ANOVA] } \\
\text { p>0.005 }\end{array}$ \\
\hline $\begin{array}{c}\text { Transmittance } \\
(\%)\end{array}$ & $\mathrm{Y}=-0,81 \mathrm{~A}+1.13 \mathrm{~B}+1.17 \mathrm{C}$ & linier & 0.0479 \\
\hline $\begin{array}{l}\text { Emulsification } \\
\text { time (seconds) }\end{array}$ & $\begin{array}{r}\mathrm{Y}= \\
\mathrm{AB}+1063,76 \mathrm{~A}-283,206 \mathrm{~B}+2974,91 \mathrm{C}-103,21 \\
(\mathrm{~A}-\mathrm{B})-0,40 \mathrm{AC}(\mathrm{A}-\mathrm{C})+0,43 \mathrm{BC}(\mathrm{B}-\mathrm{C})\end{array}$ & cubic & 0.0239 \\
\hline
\end{tabular}

The Analysis of variance (ANOVA) statistical analysis explains that the percent response of transmittance with linear model, emulsion time and SNEDDS stability using cubic model. The model shows the effect of using oil phase composition, surfactant, and co-surfactant of each formulation which should have a significant difference. Lack of fit explains the closeness of the observations to the predictions of the software. Lack of fit value should be no significant difference between the research observation result with prediction Software (Bolton and Bon, 2003). Table 2 shows that there is no significant effect on the mixture of oils, surfactants, and co-surfactants on the response parameters of emulsion time and SNEDDS stability. The transmittance response 
parameters show that the co-surfactant component gives the biggest influence that can increase the transmittance percentage with the coefficient value $+1,17$.
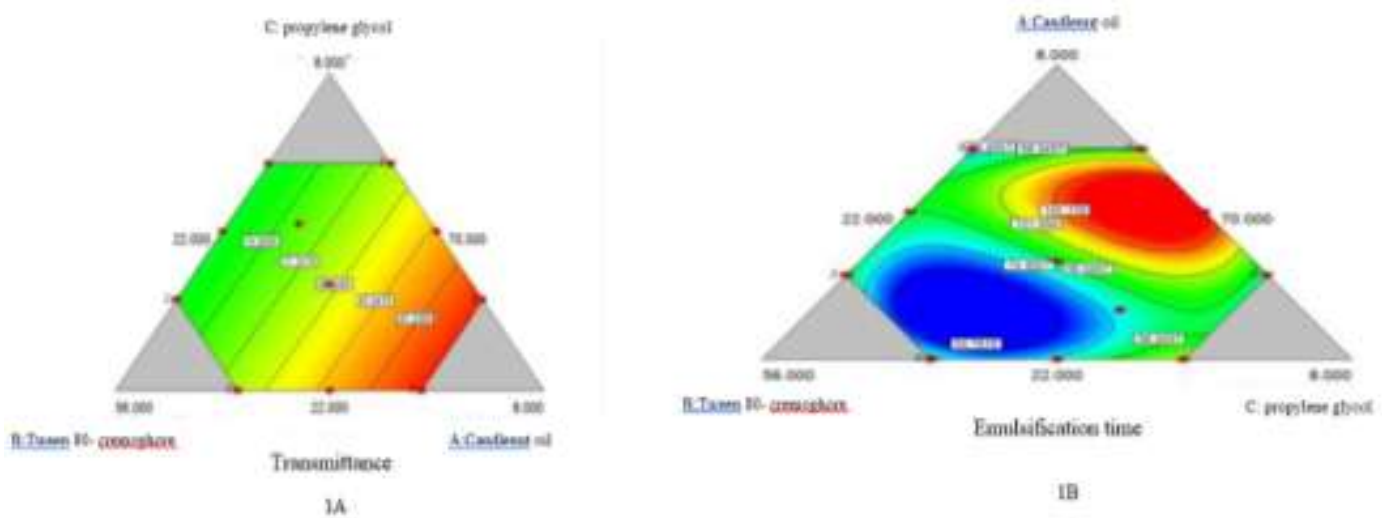

Figure 1. The counter diagram plot of SNEDDS stability response parameters transmittance [1A], emulsification time [1B]

The numbers on the triangle show the oil composition, surfactant, and co-surfactant in the model. The top response is shown in the red area, the lower the response is shown in the yellow area, and the lowest are in the green and blue area (Figure-1A). The solution chosen is the largest value and is close to 0.85 on the superimpose diagram, which means it will produce a formulation with optimal characteristics according to the target. The optimum composition proportion of candlenut oil, surfactant, and co-surfactant is 12\%: 66\%: $22 \%$. Table 2 describes the effect of components on emulsification time. The interaction factor between components produces a cubic model, this means that the interaction between components affects the emulsification time results at a more complex level.

The addition of candlenut oil has been shown to increase the emulsification time, which gives a more significant positive value than other interactions. The addition of surfactants has been shown to reduce the emulsification time, showing the most significant negative value. The increase in oil concentration caused the emulsification time to be longer, while the rise in co-surfactants was smaller so that it is not enough to form nanoemulsions in a shorter time (Beg et al., 2013). The little oil concentration and the high surfactant concentration cause the viscosity of emulsification time to be smaller (Basalious et al., 2010). The figure in the triangle shows the emulsification time indicated by the change in the composition of the oil, surfactant, and co-surfactant. Figure 1B shows the red area offers the most prolonged emulsification time response due to increased oil and co-surfactants. Then the green area shows the middle time, and the shortest time is the blue area. The faster the pre-concentration takes to form the emulsion, the better the results. The surfactant composition affects the least emulsification response in the blue area. The D-Optimal method shows the software's predictive value towards the observed response value given by the optimal formulation with a confidence level and a prediction interval of $95 \%$. Based on the results of testing the percentage of the transmission response in Table 3, there is no significant difference between the emulsification time of the optimum formulation observation and the predictive value given by the Design Expert software [p-value> 0.05]. 
Table 3. Result of verification Design Expert prediction value and observation of optimum formulation SNEDDS extract of soursop leaves

\begin{tabular}{cccc}
\hline $\begin{array}{c}\text { Physical stability } \\
\text { response }\end{array}$ & $\begin{array}{c}\text { Prediction Design } \\
\text { Expert }\end{array}$ & Observation & $\begin{array}{c}\text { Sig- } \\
\text { value } \\
\mathbf{[ p > 0 . 0 5}]\end{array}$ \\
\hline Transmittance (\%) & 90.58 & $91 \pm 0.15 \mathrm{SE}$ & 0.11 \\
\hline $\begin{array}{c}\text { Emulsification time } \\
\text { (seconds) }\end{array}$ & 59.44 & $65.67 \pm 1.76 \mathrm{SE}$ & 0.072 \\
\hline
\end{tabular}

The next process was to measure the maximum wavelength ( $\lambda$ maks) and DPPH operational time of $0.4 \mathrm{mM}$ in pro methanol analysis using UV-Vis spectrophotometry. The highest absorbance was shown at a wavelength of $516 \mathrm{~nm}$ with a working time of 40 minutes. The linear regression equation resulting from the SNEDDS activity of chloroform extract of soursop leaves is $y=$ $0.1817 x+43.408$. From this equation, the IC50 value is obtained, which means that the test solution can reduce DPPH by $50 \%$ at this concentration. The antioxidant potential of the SNEDDS formulation for chloroform extract of soursop leaves was shown by an $\mathrm{IC}_{50}$ value of $36.28 \mathrm{ppm}$ (Figure.2).

Screening phytochemical of soursop leaves chloroform extract using Thin Layer Chromatography method. In the phytochemical screening test, a comparison of soursop leaves isolates and soursop leaves extract was used to determine the profile of chemical content in SNEEDS of soursop leaves extract. According to the research of (Dewangga, 2015) the identification of isolated soursop leaves using mobile phase chloroform-ethyl acetate (7: 3) generates a purplish red spot observed under $366 \mathrm{~nm} \mathrm{U.V.} \mathrm{light} \mathrm{(Figure.} \mathrm{3).} \mathrm{The} \mathrm{result} \mathrm{showed} \mathrm{that}$ the active compounds in the soursop leaves chloroform extract as same as in the isolates of soursop leaves, and the SNEDDS compound was identical with the compounds in the extract.

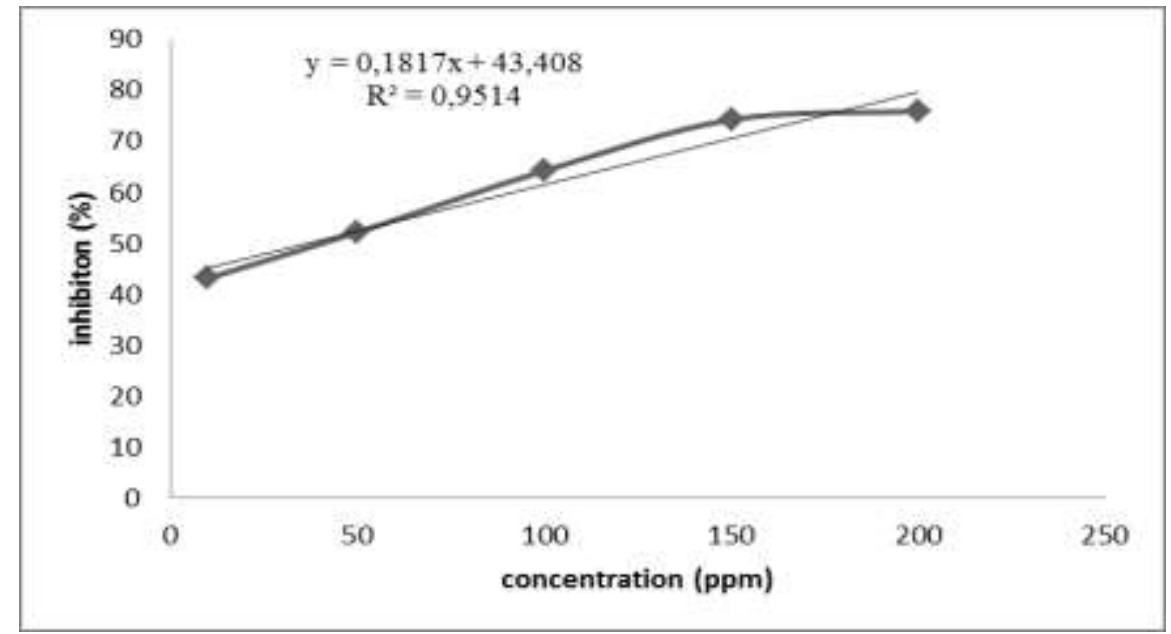

Figure 2. DPPH inhibitory activity SNEDDS formulation for chloroform extract of soursop leaves (Annona muricata L.) 


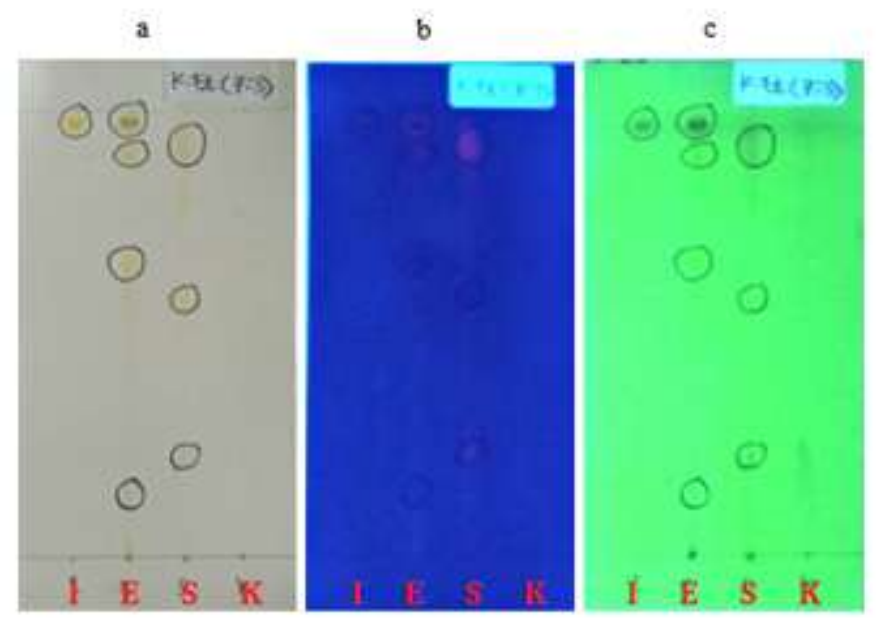

Figure 3. TLC analysis with mobile phase werw chloroform : ethyl acetate (7: 3) with Silica Gel 60 GF 254 stationary phase. Observations on visible light [a], UV 254 light [b], and UV 366 light [c]. Isolate of soursop leaves [I], soursop leaves chloroform extract [E], optimum formulation of SNEDDS soursop leaves chloroform extract [S], SNEDDS without extract [K]

\section{CONCLUSION}

The SNEDDS optimization of soursop leaves chloroform extract has SNEDDS composition of soursop leaves chloroform extract in 4 grams system that is 0,1 gram soursop leaves extract, $12 \%$ candlenut oil, $22 \%$ propylene glycol, mixed tween 80 and cremophor as much as $66 \%$. The optimum SNEDDS formulation of chloroform extract of soursop leaves produces stable, homogeneous nanoemulsion. It has a transmittance value of $91 \pm 0.15 \mathrm{SE}$ and emulsification time of $65.67 \pm 1.76 \mathrm{SE} \mathrm{sec}$ in artificial gastric fluid, and phase separation is close to 1 . An IC50 value of $36.28 \mathrm{ppm}$ indicated the antioxidant potential of the SNEDDS formulation for soursop leaves chloroform extract.

\section{ACKNOWLEDGEMENT}

Thanks to Universitas Sebelas Maret for funding this research through the Fundamental Research scheme with contract number 452 / UN27.21 / PN / 2020.

\section{REFERENCES}

Akula, S., Gurram, A. K., \& Devireddy, S. R. (2014). Self-microemulsifying drug delivery systems: an attractive strategy for enhanced therapeutic profile. International Scholarly Research Notices, 2014.

An, A., VS, D., Fitria, M. S., \& Ay, E. (2016). Tetrahydrofurane is a Component of Annona muricata Leaf will Induce Apoptosis Program in Cancer Cell because the Virus: A Proxy for Cancer Treatment. Immunome Research, 12(2), 1. https://doi.org/10.4172/17457580.10000120

Arlene, A. (2013). Ekstraksi kemiri dengan metode soxhlet dan karakterisasi minyak kemiri. Jurnal Teknik Kimia USU, 2(2), 6-10. https://doi.org/10.32734/jtk.v2i2.1430

Basalious, E. B., Shawky, N., \& Badr-Eldin, S. M. (2010). SNEDDS containing bioenhancers for improvement of dissolution and oral absorption of lacidipine. I: Development and optimization. International Journal of Pharmaceutics, 391(1-2), 203-211. https://doi.org/10.1016/j.ijpharm.2010.03.008 
Beg, S., Jena, S. S., Patra, C. N., Rizwan, M., Swain, S., Sruti, J., Rao, M. E. B., \& Singh, B. (2013). Development of solid self-nanoemulsifying granules (SSNEGs) of ondansetron hydrochloride with enhanced bioavailability potential. Colloids and Surfaces B: Biointerfaces, 101, 414-423. https://doi.org/10.1016/j.colsurfb.2012.06.031

Bolton, S., \& Bon, C. (2003). Pharmaceutical statistics: Practical and clinical applications, fourth edition, revised and expanded. In Pharmaceutical Statistics: Practical and Clinical Applications, Fourth Edition, Revised and Expanded. CRC press.

Borhan, F. P., Abd Gani, S. S., \& Shamsuddin, R. (2014). The use of D-optimal mixture design in optimising okara soap formulation for stratum corneum application. Scientific World Journal, 2014. https://doi.org/10.1155/2014/173979

Carmona, M. A., Lafont, F., Jiménez-Sanchidrián, C., \& Ruiz, J. R. (2015). Characterization of macadamia and pecan oils and detection of mixtures with other edible seed oils by Raman spectroscopy. Grasas y Aceites, 66(3), 94. https://doi.org/10.3989/gya.1191142

Cicilia, F. S. (2016). Pengaruh Nilai HLB (Hydrophile-Lipophile Balance) Campuran Surfaktan Polysorbate 80 dan Cetyl Alcohol Terhadap Stabilitas Fisik Losion VCO (Virgin Coconut Oil). Fakultas Farmasi, Universitas Sanata Dharma.

Costa, J. A., Lucas, E. F., Queirós, Y. G. C., \& Mansur, C. R. E. (2012). Evaluation of nanoemulsions in the cleaning of polymeric resins. Colloids and Surfaces A: Physicochemical and Engineering Aspects, 415, 112-118. https://doi.org/10.1016/j.colsurfa.2012.10.011

Desmiaty, Y., Rahmat, D., \& Sari, M. . (2015). Preparation of Standardized Aqueous extract of Annona Muricata Linn. Leaf, Its potency as antioxidant and total flavonoid content assay. Peoceeding International Seminar of POKJANAS TOI 49th, 30.

Dewangga, V. S. (2015). Karakterisasi isolat aktif daun sirsak ( Annona muricata L .) dan uji sitotoksisitas isolat. UNS (Sebelas Maret University).

Goyal, U., Arora, R., \& Aggarwal, G. (2012). Formulation design and evaluation of a selfmicroemulsifying drug delivery system of lovastatin. Acta Pharmaceutica, 62(3), 357-370. https://doi.org/10.2478/v10007-012-0022-1

Lovelyn, C., \& Attama, A. A. (2011). Current State of Nanoemulsions in Drug Delivery. Journal of Biomaterials and Nanobiotechnology, 626-639. https://doi.org/10.4236/jbnb.2011.225075

Maharani, D. Y. (2016). Formulasi bahan pengenyal dalam produksi Marshmallow ekstrak daun Black Mulberry (Morus Nigra). Fakultas Teknik Unpas.

Makadia A. H, Ami Y. Bhatt, Ramesh B. Parmar, Jalpa S. Paun, \& H. M. Tank. (2013). Self-nano Emulsifying Drug Delivery System (SNEDDS): Future Aspects | Makadia | Asian Journal of Pharmaceutical Research. Asian Journal of Pharmaceutical Research, 3(1), 21-27. http://www.i-scholar.in/index.php/Ajpr/article/view/42755

Martien, R., Adhyatmika, Irianto, I. D. K., Farida, V., \& Sari, D. P. (2012). Perkembangan teknologi nanopartikel sebagai sistem penghantaran obat. Majalah Farmaseutik, 8(1), 133144.

Moghadamtousi, S. Z., Fadaeinasab, M., Nikzad, S., Mohan, G., Ali, H. M., \& Kadir, H. A. (2015). Annona muricata (Annonaceae): A review of its traditional uses, isolated acetogenins and biological activities. In International Journal of Molecular Sciences (Vol. 16, Issue 7, pp. 15625-15658). Multidisciplinary Digital Publishing Institute. https://doi.org/10.3390/ijms160715625

Zen, N. I.M, Abd Gani, S. S., Shamsudin, R., \& Fard Masoumi, H. R. (2015). The use of D-optimal mixture design in optimizing development of okara tablet formulation as a dietary supplement. Scientific World Journal, 2015, 1-8. https://doi.org/10.1155/2015/684319

Nasr, A., Gardouh, A., \& Ghorab, M. (2016). Novel solid self-nanoemulsifying drug delivery system (S-SNEDDS) for oral delivery of olmesartan medoxomil: Design, formulation, pharmacokinetic and bioavailability evaluation. Pharmaceutics, 8(3), 20. 
https://doi.org/10.3390/pharmaceutics8030020

Pratiwi, D. R., Bintang, M., \& Simanjuntak, P. (2014). Lelutung tokak (Tabernaemontana macrocarpa Jack.) sebagai sumber zat bioaktif antioksidan dan antikanker. Jurnal Ilmu Kefarmasian Indonesia, 12(2), 267-272.

Savale, S.,K. (2015). A review - self nanoemulsifying drug delivery system (SNEDDS). International Journal of Research in Pharmaceutical and Nano Sciences, 4(6), 385-397 